\title{
Traditional Eastern Spanish varieties of tomato
}

\author{
Carles Cortés-Olmos ${ }^{1}$, José Vicente Valcárcel ${ }^{1}$, Josep Roselló², Maria José Díez ${ }^{1}$, Jaime Cebolla-Cornejo ${ }^{1 *}$
}

\begin{abstract}
'Universitat Politècnica de València/Instituto Universitario de Conservación y Mejora de la Agrodiversidad Valenciana (Polytechnic University of Valencia, Institute for the Conservation and Improvement of Valentian Agrodiversity), Camino de Vera, s/n. - 46022 - València. Spain. 2Instituto Valenciano de Investigaciones Agrarias/Estación Experimental Agraria de Carcaixent (Valencian Institute for Agricultural Research/Agricultural Experimentation Station of Carcaixent), C/ Partida Barranquet, s/n. - 46740 Carcaixent, Spain.

'Corresponding author <jaicecor@btc.upv.es>
\end{abstract}

Edited by: Leonardo Oliveira Medici

Received September 16, 2014

Accepted March 16, 2015

\begin{abstract}
Despite the importance of traditional varieties of tomato (Solanum lycopersicum L.) as sources of variation in breeding programs and varieties targeted to high-price quality markets that value their exceptional organoleptic quality, little is known regarding the structure of these materials at the morphological level. In this study, a collection of 166 populations (137 of them during two years) of traditional varieties of tomato from the east coast of Spain has been characterized using 41 descriptors. The characterization revealed a considerable variation. The segregation observed in several populations (28\%) suggests that apart from the configuration as population varieties, the high variation present in these landraces may be partially due to possible seed mixing and spontaneous cross-pollination. Only nine fruit descriptors were required to represent the variation present in the collection analyzed. It seems that after spontaneous crosspollinations, farmers applied strong selection to a small number of traits, though even in these traits a high level of variation is maintained. The variation observed may hinder clear recognition by the consumer, an attribute required for the consolidation of quality markets. Additionally, a registry of these materials as conservation varieties would be complicated considering the actual levels of variation. Therefore, a varietal depuration would be interesting in order to promote in situ conservation of these resources. Finally, the high levels of variation in the intra-varietal scale may justify the collection and maintenance of more populations of the same variety as the risk of conserving duplicates would not be so high.

Keywords: Solanum lycopersicum, genetic resources, breeding, genebank
\end{abstract}

\section{Introduction}

The tomato (Solanum lycopersicum L.) was domesticated in Meso-America (Jenkings, 1948) and was taken by Spaniards to Europe, probably during the first half of the $16^{\text {th }}$ century. As the first nation to relocate this fruit from its original centre of domestication and as one of the first to accept it into their diet, Spain now boasts considerable diversity in tomato variety, especially those grown on its east coast. This great diversity which has been generated over centuries of cultivation, is distributed at various levels. The selection performed by traditional farmers tended to configure varieties as mixtures of genotypes and common external features. Additionally, each farmer performed a different selection and thus, in each variety (defined by certain morphological attributes) there might be as many different populations as farmers cultivating them.

All this diversity rapidly declined during the $20^{\text {th }}$ century as a result of the industrialization of agriculture and the advance of plant breeding programs. Part of this diversity was collected and conserved in germplasm banks. The Spanish National Inventory contains 2,634 accessions of tomato conserved in different Spanish institutions, and from them $15 \%$ were collected in Comunidad Valenciana on the East Coast (source: http://www.inia.es).

Little is known of the origin of these varieties or how these traditional varieties are structured. Older agronomical books do not describe the cultivated varieties but make reference to the name or to a number of variants in shape (Junta Consultiva Agraria, 1914). Furthermore, several local names make reference to the area of collection (e.g. the name of the town or county) or to its use (e.g. salad tomato) only. It is therefore necessary to clarify if these designations correspond to specific varieties or if they can be ascribed to a certain existing variety and the general designation in passport data corresponds to inaccurate recording during collections.

Several efforts have been made to characterize Spanish materials (Alonso et al., 2009; García-Martínez et al., 2006, 2013; Casals et al., 2011, 2012; CebollaCornejo et al., 2013). However few of them analyze morphological data, and either they are usually restricted to one or few varieties, or the varieties analyzed have in general ambiguous designations (e.g. Gragera-Facundo et al., 2011).

In this context, this study mainly aims to continue previous efforts (Cebolla-Cornejo et al., 2013) to characterize a different set of populations and increase the number of varieties. This considerably large set of populations belonging to traditional varieties typical of the East Coast of Spain will enable a further study that will focus on how they are structured. This information would be of great value in the promotion of on-farm conservation of this diversity as well as to the provision of new information for the management of germplasm banks.

\section{Materials and Methods}

\section{Plant material}

A total of 166 populations of traditional varieties of tomato (Solanum lycopersicum L.) were characterized during the year 2009 (Table 1). All of them are conserved at the germplasm bank of the COMAV /Valencia, 
Spain). Most of them, 152, were provided by this bank while 14 were provided by the IVIA (Moncada, Spain). One population of "De colgar" and three populations of "Valenciano" were purchased in local nurseries as controls (marked LN in Table 1). As commercial references, four F1 hybrids were included in the study to represent different fruit sizes. "Razymo RZ" (figure code R) has round, red, medium-sized fruit, "Gransol RZ" (figure code G) slightly flattened, large-sized fruit", "Piccota RZ" (figure code P) round, small-sized fruit and "Mariscal RZ" (figure code M) flattened, medium to large-sized fruit.

Several of the populations (46) had intense segregation (mixed morphotypes in continuous gradient or discrete segregation) and were not further characterized.
Considering these results, a set of 137 populations, four populations obtained from local nurseries as controls and the four reference hybrids were again characterized in a second assay during the year 2010 using the same methodology (Table 1).

\section{Crop Conduction and Experimental Design}

The seedbeds were sown in April and transplanted in May 2009 and 2010. The crop was cultivated in a $5,800 \mathrm{~m}^{2}$ field located in Carcaixent $\left(+39^{\circ} 6^{\prime \prime} 37.13^{\prime \prime}\right.$, $-0^{\circ} 26^{\prime \prime} 45.05^{\prime \prime}$, Valencia, Spain), surrounded by orange trees. The field had been previously fertilized with $36,000 \mathrm{~kg}$ of sheep manure and $200 \mathrm{~kg}$ of potassium sulphate.

Table 1 - Origin of the populations characterized and description of the traditional varieties evaluated (numbers within the parentheses indicate the code used for the representation in the figures: variety.accession; W.A.= Without previous clear ascription in passport data; segregants in the 2009 campaign are marked with *; populations re-ascribed from a different variety are indicated as ex-former variety code; $\mathrm{VC}=\mathrm{Valencia}$; $\mathrm{AL}=$ Alicante; $\mathrm{CS}=$ Castelló; $\mathrm{LN}=$ Local nursery).

\begin{tabular}{|c|c|}
\hline Variety & on/populations (code, town, province) \\
\hline Amarillo (1) & $\begin{array}{l}\text { Description: Large sized flattened and ribbed yellow tomatoes with a high locule number (more than 20). These tomatoes are typical of } \\
\text { inland areas. } \\
\text { Populations: CDP01733* (Casas Altas, VC) (1.1), CDP06618 (Casas Altas, VC) (1.2). }\end{array}$ \\
\hline Centenares (2) & $\begin{array}{l}\text { Description: Very small sized round fruit with intense red coloration. } \\
\text { Populations: CDP08734 (Rincón de Ademuz, VC) (2.1). }\end{array}$ \\
\hline Cuarenteno (3) & $\begin{array}{l}\text { Description: Intermediate sized flattened ribbed fruit with green persistent shoulders. Early production. } \\
\text { Populations: CDP07243 (Chelva, VC) (3.1), CDP07457 (Aldaya, VC) (3.2), CDP09667 (Torrente, VC) (3.3), CDP04955 (Rojales, AL) } \\
\text { (3.4), CDP07499 (Sueca, VC) (3.5), CDP08237 (Massamagrell,VC) (3.6), CDP07843 (VC) (3.7), CDP01864 (ex W.A.) (Anna, VC) (3.8). }\end{array}$ \\
\hline De colgar (4) & $\begin{array}{l}\text { Description: Small sized round or oblong fruit with two or three locules. Transparent or yellow skin and thick pericarp. With delayed } \\
\text { ripening (alc)), these tomatos are harvested and conserved hanging in fresh and aerated places. } \\
\text { Populations: CDP05385 (Torrebaja, VC) (4.1), CDP08528 (Sarratella, CS) (4.2), CDP05079 (Líria, VC) (4.3), CDP06914* (Náquera, } \\
\text { VC) (4.4), CDP01507 (Benicarló, CS) (4.5), CDP01040 (ex W.A.) (Camporrobles, VC) (4.6), CDP04259* (ex W.A.) (Xàtiva, VC) (4.7), } \\
\text { CDP03190 (La PLana, CS) (4.8), CDP02554* (Montroi, VC) (4.9), CDP01972 (Xàbia, AL) (4.10), CDP01025 (Viveros Cucala, LN) (4.11). }\end{array}$ \\
\hline De la pera (5) & $\begin{array}{l}\text { Description: Mid-sized pear shaped fruit with two or three locules. Thick pericarp and hollowness are common. } \\
\text { Populations: CDP02614 (Chelva, VC) (5.1), CDP00210* (ex 6) (Novelda, AL) (5.2), CDP00906 (La Aparecida, AL) (5.3), CDP07874 } \\
\text { (Orihuela, AL) (5.4). }\end{array}$ \\
\hline De pera (6) & $\begin{array}{l}\text { Description: Small sized round or oblong fruit. Usually used for cooking. } \\
\text { Populations: CDP04299 (Hostalet de Benasal, CS) (6.1), CDP01280 (Ademuz, VC) (6.2), CDP00929 (ex W.A.) (Poble Nou, VC) (6.3), } \\
\text { CDP06418 (ex W.A.) (Valencia, VC) (6.4). }\end{array}$ \\
\hline Elchero (7) & $\begin{array}{l}\text { Description: Mid-sized red tomatoes with round shape and angular section. Usually slightly ribbed, with } 2 \text { or } 3 \text { locules. } \\
\text { Populations: CDP07339 (Muchamiel, AL) (7.1). }\end{array}$ \\
\hline Flor de baladre (8) & $\begin{array}{l}\text { Description: Large sized slightly flattened ribbed fruits with pink color. } \\
\text { Populations: CDPO4235* (Elche, AL) (8.1), CDP07166* (Valencia, VC) (8.2). }\end{array}$ \\
\hline Gordo rojo (9) & $\begin{array}{l}\text { Description: Very large sized flattened and ribbed fruits. Typical of inland areas. } \\
\text { Populations: CDP05229 (ex “Marmande”) (Viver, CS) (9.1), CDP02826* (ex W.A.) (Millares, VC) (9.2), CDP08786 (ex 17) (Arañuel, CS) } \\
\text { (9.3), CDP06270 (ex W.A.) (Carcaixent, VC) (9.4), CDP06009 (ex W.A.) (Valencia, VC) (9.5). }\end{array}$ \\
\hline Muchamiel (10) & $\begin{array}{l}\text { Description: Large sized flattened and strongly ribbed fruit. With numerous locules, big peduncular scar and corky area and thick } \\
\text { pericarp. Persistent green shoulders, orange-red ripe color. It is a late variety. } \\
\text { Populations: CDP05658 (Novelda, AL) (10.1), CDP04133 (La Aparecida, AL) (10.2), CDP00155* (Elche, AL) (10.3), CDP07582 (San } \\
\text { Juan, AL) (10.4), CDP08091 (Campello, AL) (10.5), CDP01469 (San Juan, AL) (10.6), CDP08014 (San Juan, AL) (10.7), CDP01988 } \\
\text { (Muchamiel, AL) (10.8), CDP09344 (Muchamiel, AL) (10.9), CDP02195 (Muchamiel, AL) (10.10), CDP08780 (Muchamiel, AL) (10.11), } \\
\text { CDP08427 (Muchamiel, AL) (10.12), CDP07052 (Muchamiel, AL) (10.13), CDP08797 (Muchamiel, AL) (10.14), CDP04512 (Muchamiel, } \\
\text { AL) (10.15), CDP05422 (Muchamiel, AL) (10.16), CDP00604 (Muchamiel, AL) (10.17), CDP03096 (Orihuela, AL) (10.18), CDP08048* } \\
\text { (San Juan, AL) (10.19), CDP01971 (San Juan, AL) (10.20), CDP05938 (Alboraya, VC) (10.21), CDP01138 (San Juan, AL) (10.22), } \\
\text { CDP01746 (Orihuela, AL) (10.23), CDP08999 (San Juan, AL) (10.24), CDP08761 (Catarroja, VC) (10.25), CDP09432 (Llíria, VC) (10.26). }\end{array}$ \\
\hline Negro (11) & $\begin{array}{l}\text { Description: Large sized flattened fruit with dark purple coloration. } \\
\text { Populations: CDPO2095* (ex W.A.) (Torrent, VC) (11.1). }\end{array}$ \\
\hline Pimiento (12) & $\begin{array}{l}\text { Description: Mid-sized elongated fruit (similar to "Italian" peppers) with intense red color and green persistent shoulders, two to four } \\
\text { locules and moderate radial cracking. Used for cooking. } \\
\text { Populations: CDP06083* (Venta del Moro, VC) (12.1), CDP04079 (Jérica, CS) (12.2), CDP06446 (Fontanares, VC) (12.3), CDP05734 } \\
\text { (Villahermosa del Río, CS) (12.4), CDP01712 (Alborache, VC) (12.5), CDP09096 (Yátova, VC) (12.6), CDP04056 (Catarroja, VC) (12.7), } \\
\text { CDP07194 (Moncada, VC) (12.8), CDP08320 (ex 3) (Massamagrell, VC) (12.9). }\end{array}$ \\
\hline
\end{tabular}


Table 1 - Continuation.

\begin{tabular}{|c|c|}
\hline $\operatorname{Raf}(13)$ & $\begin{array}{l}\text { Description: Derived from one of the first varieties with Fusarium oxysporum lycopersici resistence. This is an obsolete variety, not a } \\
\text { real traditional variety. Intensely ribbed flat fruit with marked green shoulders. } \\
\text { Populations: CDP00068 (Alicante, AL) (13.1). }\end{array}$ \\
\hline Redondo rojo (14) & $\begin{array}{l}\text { Description: Mid to large sized round red fruit. } \\
\text { Populations: CDP07064* (ex 3) (Sueca, VC) (14.1), CDP04562 (ex W.A.) (Carcaixent, VC) (14.2). }\end{array}$ \\
\hline Rosa (15) & $\begin{array}{l}\text { Description: Very large sized flat fruit with variable levels of ribbing. Transparent skin and pink color. Typical of inland areas. } \\
\text { Populations: CDPO2968* (Albocácer, CS) (15.1), CDP08690 (Fontanares, VC) (15.2), CDP05702* (Castillo de Villamalefa, CS) (15.3), } \\
\text { CDP04903 (Onda, CS) (15.4), CDP00764* (Aras del Alpuente, VC) (15.5), CDP01302* (Rincón de Ademuz, VC) (15.6), CDP09459* } \\
\text { (Yátova, VC) (15.7), CDP04904 (Alboraya, VC) (15.8), CDP05992* (Requena, VC) (15.9), CDP05438* (ex W.A.) (Cofrentes, VC) } \\
\text { (15.10), CDP07166 (ex 8) (VC) (15.11), CDP07661 (Todolella, CS) (15.12), CDP03526 (Sellent, VC) (15.13), CDP04303 (ex W.A.) } \\
\text { (Valencia, VC) (15.14), CDP04008 (ex W.A.) (Valencia, VC) (15.15). }\end{array}$ \\
\hline Tres cantos (16) & $\begin{array}{l}\text { Description: Large sized round red fruit with angular section. } \\
\text { Populations: CDP06491 (ex W.A.) (Carcaixent, VC) (16.1) }\end{array}$ \\
\hline Vale & 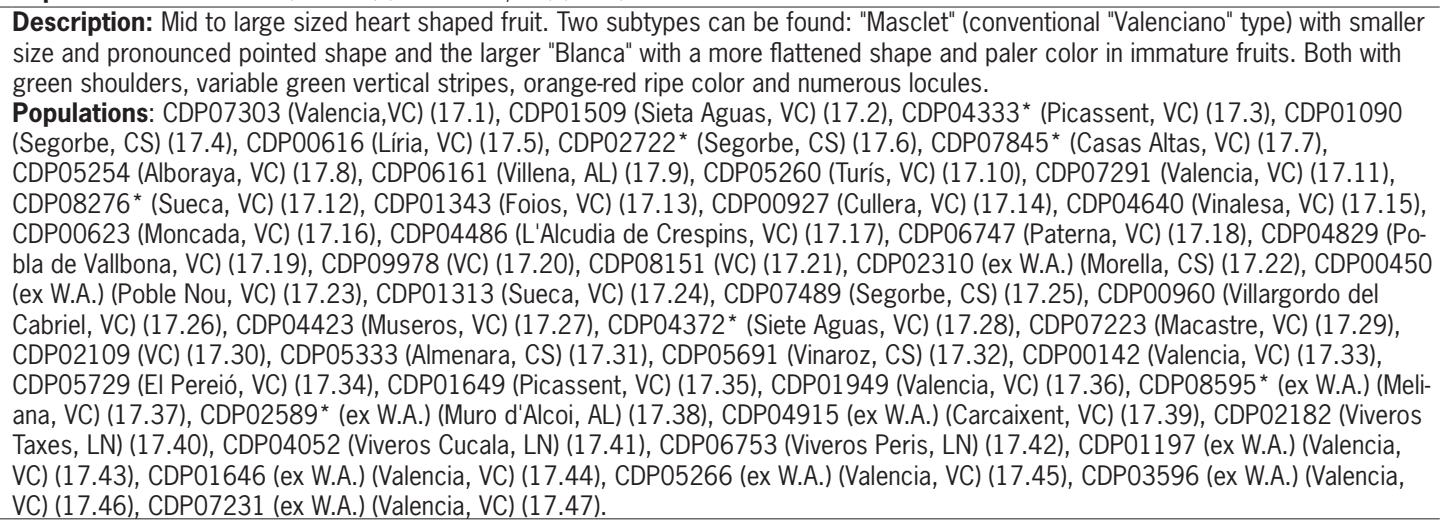 \\
\hline Valer & $\begin{array}{l}\text { Description: Mid-sized heart shaped tomatoes similar to "Valenciano" but with pinkish color. } \\
\text { Populations: CDP04138* (ex 17) (Valencia, VC) (18.1). }\end{array}$ \\
\hline
\end{tabular}

A randomized complete block design was used with two blocks, and 20 plants per population and block. A spacing of $1.2 \mathrm{~m} \times 0.4 \mathrm{~m}\left(2.1\right.$ plants $\left.\mathrm{m}^{-2}\right)$ was applied. The crop was managed using the traditional practices for tomato cultivation in the area, including staking, pruning, and drip fertirrigation. To control the Tuta absoluta population, traps were used and pesticide treatments were applied weekly depending on insect counts.

\section{Morpho-agronomic characterization}

A group of 41 tomato descriptors (marked I-) from the International Plant Genetic Resources Institute's guidelines (IPGRI, 1996) complemented with added descriptors selected considering previous experience with the crop (marked A-), were used to study the morphoagronomic variation (Table 2). Qualitative descriptors were classified on scales from 1 to 7 , considering 1 as extremely low intensity and 7 as extremely high intensity. Although the external color of ripe fruit was evaluated qualitatively, a quantitative estimation using Hunter coordinates $(\mathrm{a} / \mathrm{b}$ rate) with a colorimeter was also obtained (average of ten representative fruits and three determinations for each fruit). Plant, flower and inflorescence characters were evaluated in each plant. Fruit characterization was performed using a pool of at least 20 fruits to represent the fruit variability of each block. The fruits were harvested at the mature-red stage, from the second to the third truss.

\section{Statistical Analysis}

A subset of 145 populations evaluated over both years was selected to study the structure and variability among varieties. This variation was analysed statistically using principal component analysis (PCA). The number of principal components to be included in the analysis of the results was determined following the criterion described by Krzanowski (2000). A first PCA was performed including all the variables. From this starting point, different PCA were derived removing a different variable each time. Following this procedure, a final second PCA with nine variables was obtained considering the following criteria: maximum explanation of variance in the first two principal components and a distribution similar to that found in the complete PCA.

Phenotypic variation was calculated using different coefficients of variation. In each campaign three coefficients of variation at different levels were calculated. Results were finally expressed as the mean coefficient for both campaigns. Coefficient of variation of the whole collection (CCV) for a trait was calculated as the coefficient of variation among the mean values for the trait considering all the populations characterized. Intra-accession coefficient of variation (IACV) for a trait was calculated as the coefficient of variation of the values obtained from the plants of a single accession. Mean IACV considering all the populations and maximum and minimum IACV were calculated. Intra- 
Table 2 - Variability found in the traits characterized, including coefficient of variation of the whole collection (CCV), mean intra-accession coefficient of variation (IACV) and intra-varietal coefficient of variation (IVCV). Values determined in terms of mean coefficients for two years (2009 and 2010).

\begin{tabular}{|c|c|c|c|c|c|c|c|}
\hline \multirow{2}{*}{ Trait (I:IPGRI, A: Internal) } & \multirow{2}{*}{$\begin{array}{l}\mathrm{CCV}^{1} \\
\text { Mean }\end{array}$} & \multicolumn{3}{|c|}{$\mathrm{IACV}^{2}$} & \multicolumn{3}{|c|}{$\mathrm{IVCV}^{3}$} \\
\hline & & Mean & Min & Max & Mean & Min & Max \\
\hline A-Approximate density $\left(\mathrm{g} \mathrm{mm}^{-3}\right)$ & $0.23 \pm 0.16$ & $0.21 \pm 0.11$ & 0.00 & 0.57 & $0.12 \pm 0.07$ & 0.01 & 0.75 \\
\hline I-Concentric cracking & $1.12 \pm 0.24$ & $0.72 \pm 0.59$ & 0.00 & 3.08 & $1.16 \pm 0.22$ & 0.00 & 2.52 \\
\hline A-Core height $(\mathrm{mm})$ & $0.32 \pm 0.00$ & $0.27 \pm 0.02$ & 0.00 & 0.54 & $0.23 \pm 0.08$ & 0.01 & 0.49 \\
\hline A-Core width (mm) & $0.43 \pm 0.11$ & $0.30 \pm 0.04$ & 0.00 & 0.59 & $0.27 \pm 0.03$ & 0.07 & 0.86 \\
\hline A-Core width/fruit width ratio & $0.22 \pm 0.02$ & $0.18 \pm 0.06$ & 0.00 & 0.68 & $0.14 \pm 0.06$ & 0.01 & 0.27 \\
\hline I-External color of immature fruit & $0.38 \pm 0.14$ & $0.15 \pm 0.07$ & 0.00 & 0.77 & $0.25 \pm 0.08$ & 0.00 & 0.64 \\
\hline I-External ripe fruit color & $0.15 \pm 0.02$ & $0.05 \pm 0.02$ & 0.00 & 0.26 & $0.07 \pm 0.03$ & 0.00 & 0.17 \\
\hline A-Flower fasciation & $0.59 \pm 0.34$ & $0.17 \pm 0.04$ & 0.00 & 1.90 & $0.50 \pm 0.39$ & 0.00 & 1.79 \\
\hline I- Foliage density & $0.09 \pm 0.01$ & $0.02 \pm 0.01$ & 0.00 & 0.13 & $0.08 \pm 0.02$ & 0.00 & 0.33 \\
\hline I-Fruit blossom end shape & $0.31 \pm 0.01$ & $0.11 \pm 0.02$ & 0.00 & 0.49 & $0.23 \pm 0.01$ & 0.00 & 0.47 \\
\hline A-External ripe fruit color (Hunter $\mathrm{a} / \mathrm{b}$ ratio) & $0.29 \pm 0.03$ & $0.27 \pm 0.04$ & 0.00 & 1.97 & $0.20 \pm 0.07$ & 0.05 & 0.71 \\
\hline A-Fruit conservation & $4.09 \pm 0.00$ & $0.00 \pm 0.00$ & 0.00 & 0.00 & $0.27 \pm 0.00$ & 0.00 & 3.87 \\
\hline I-Fruit cross-sectional shape & $0.45 \pm 0.07$ & $0.04 \pm 0.04$ & 0.00 & 0.26 & $0.33 \pm 0.03$ & 0.00 & 0.58 \\
\hline I-Fruit height (mm) & $0.24 \pm 0.01$ & $0.10 \pm 0.00$ & 0.00 & 0.27 & $0.13 \pm 0.05$ & 0.01 & 0.35 \\
\hline I-Fruit shape & $0.67 \pm 0.01$ & $0.14 \pm 0.06$ & 0.00 & 0.73 & $0.36 \pm 0.13$ & 0.00 & 0.75 \\
\hline I-Fruit shoulder shape & $0.26 \pm 0.00$ & $0.10 \pm 0.05$ & 0.00 & 0.35 & $0.19 \pm 0.04$ & 0.00 & 0.40 \\
\hline I-Fruit weight (g) & $0.40 \pm 0.02$ & $0.24 \pm 0.02$ & 0.00 & 0.39 & $0.29 \pm 0.09$ & 0.04 & 0.51 \\
\hline I- Fruit width (mm) & $0.20 \pm 0.01$ & $0.10 \pm 0.00$ & 0.00 & 0.25 & $0.12 \pm 0.05$ & 0.00 & 0.25 \\
\hline A-Fruit width/fruit height ratio & $0.40 \pm 0.14$ & $0.23 \pm 0.12$ & 0.00 & 0.59 & $0.22 \pm 0.02$ & 0.01 & 0.86 \\
\hline I-Inflorescence type & $0.29 \pm 0.05$ & $0.17 \pm 0.04$ & 0.00 & 0.55 & $0.24 \pm 0.08$ & 0.00 & 0.47 \\
\hline I-Intensity of fruit ribbing & $0.53 \pm 0.08$ & $0.16 \pm 0.09$ & 0.00 & 0.60 & $0.35 \pm 0.05$ & 0.00 & 0.85 \\
\hline I-Internal ripe fruit color & $0.13 \pm 0.01$ & $0.01 \pm 0.01$ & 0.00 & 0.10 & $0.08 \pm 0.03$ & 0.00 & 0.22 \\
\hline I-Leaf type & $0.04 \pm 0.00$ & $0.00 \pm 0.00$ & 0.00 & 0.01 & $0.02 \pm 0.01$ & 0.00 & 0.18 \\
\hline I-Leaves attitude & $0.16 \pm 0.00$ & $0.02 \pm 0.01$ & 0.00 & 0.17 & $0.15 \pm 0.02$ & 0.00 & 0.24 \\
\hline I-Number of locules & $0.42 \pm 0.02$ & $0.24 \pm 0.02$ & 0.00 & 0.52 & $0.26 \pm 0.09$ & 0.01 & 0.73 \\
\hline I-Pericarp thickness (mm) & $0.13 \pm 0.04$ & $0.18 \pm 0.02$ & 0.00 & 0.36 & $0.10 \pm 0.02$ & 0.00 & 0.21 \\
\hline A-Pericarp thickness/fruit width ratio & $0.20 \pm 0.08$ & $0.15 \pm 0.04$ & 0.00 & 0.38 & $0.13 \pm 0.08$ & 0.01 & 0.41 \\
\hline I-Plant growth type & $0.14 \pm 0.00$ & $0.01 \pm 0.00$ & 0.00 & 0.14 & $0.08 \pm 0.02$ & 0.00 & 0.40 \\
\hline A-Plant vigor & $0.10 \pm 0.00$ & $0.04 \pm 0.00$ & 0.00 & 0.35 & $0.07 \pm 0.00$ & 0.00 & 0.26 \\
\hline A-Presence of green stripes in immature fruits & $1.03 \pm 0.17$ & $0.70 \pm 0.35$ & 0.00 & 2.45 & $0.94 \pm 0.19$ & 0.00 & 2.83 \\
\hline I-Presence of green shoulders in immature fruits & $0.31 \pm 0.01$ & $0.11 \pm 0.03$ & 0.00 & 0.44 & $0.26 \pm 0.04$ & 0.00 & 0.76 \\
\hline A-Presence of green shoulders in mature fruits & $0.30 \pm 0.01$ & $0.15 \pm 0.07$ & 0.00 & 0.94 & $0.33 \pm 0.01$ & 0.00 & 1.15 \\
\hline A-Presence of green stripes in mature fruit & $1.91 \pm 0.99$ & $0.34 \pm 0.04$ & 0.00 & 1.61 & $1.04 \pm 0.23$ & 0.00 & 3.87 \\
\hline A-Presence of vegetative shoots in the inflorescence & $1.78 \pm 0.01$ & $0.61 \pm 0.05$ & 0.00 & 4.58 & $1.36 \pm 0.02$ & 0.00 & 3.00 \\
\hline I-Presence/absence of jointless pedicel & $0.11 \pm 0.01$ & $0.00 \pm 0.00$ & 0.00 & 0.09 & $0.06 \pm 0.04$ & 0.00 & 1.15 \\
\hline I-Radial cracking & $0.62 \pm 0.11$ & $0.60 \pm 0.54$ & 0.00 & 4.47 & $0.67 \pm 0.20$ & 0.19 & 1.41 \\
\hline I-Shape of pistil scar & $0.35 \pm 0.04$ & $0.22 \pm 0.04$ & 0.00 & 0.73 & $0.33 \pm 0.12$ & 0.03 & 0.76 \\
\hline I-Skin color of ripe fruit & $0.21 \pm 0.01$ & $0.01 \pm 0.01$ & 0.00 & 0.17 & $0.09 \pm 0.05$ & 0.00 & 0.38 \\
\hline I-Stem pubescence & $0.15 \pm 0.06$ & $0.04 \pm 0.00$ & 0.00 & 0.24 & $0.12 \pm 0.06$ & 0.00 & 0.35 \\
\hline I-Style position & $0.46 \pm 0.02$ & $0.09 \pm 0.01$ & 0.00 & 0.47 & $0.34 \pm 0.03$ & 0.00 & 0.48 \\
\hline I-Width of pedicel scar & $0.27 \pm 0.03$ & $0.07 \pm 0.04$ & 0.00 & 0.39 & $0.18 \pm 0.06$ & 0.00 & 0.47 \\
\hline
\end{tabular}

${ }^{1}$ Coefficient of variation of the whole collection (CCV): coefficient of variation from the mean values for the trait considering all the populations characterized.; ${ }^{2}$ ntraaccession coefficient of variation (IACV): coefficient of variation of the values derived from the plants in a single accession; ${ }^{3}$ intra-varietal coefficient of variation (IVCV): coefficient of variation of the means of the $n$ populations of each variety.

varietal (IVCV) coefficient of variation for a trait was calculated as the coefficient of variation of the means of the $n$ populations of each variety. Mean coefficient of variation considering all the varieties and maximum and minimum IVCV were calculated. For each variety IACV and IVCV were calculated as the mean coefficient for all the traits.

\section{Results}

Out of the 166 populations characterized during the year 2009 (excluding the four varieties purchased in local nurseries), 136 corresponded to the expected variety, 23 populations did not have a specific local name during collection but showed the typical attributes of a 
certain variety and seven of them did not correspond to the variety expected and were re-classified.

Out of the whole set of 166 populations, 120 did not segregate, showing a certain morphology. The remaining 46 populations, (28\% of the total), segregated showing clearly different fruit morphologies. Thirteen of these 46 populations had been previously multiplied (mainly by collaborators of the COMAV genebank). Eight out of these thirteen populations showed a continuous gradient of variation, and were probably originated by spontaneous crossings during multiplication. The other five showed a clearly differentiated sub-population structure and were probably originated as a consequence of seed mixing. The remaining 33 populations of the 46 segregating populations corresponded to original seed directly obtained from the farmer. Of these cases, $39 \%$ of the populations had a continuous gradient of variation and were probably originated after spontaneous crosses, 46 $\%$ of the populations showed a clearly differentiated sub-population structure with several differences between populations and $15 \%$ showed a clear differentiated sub-population structure differing only in a single trait (mainly fruit color, pink or red). In cases where subpopulations could be distinguished, the sub-populations were collected separately generating new populations.

These segregants were cultivated during 2010 in order to confirm if the variation was generated by seed mixing (in which case the sub-population would maintain its traits) or spontaneous crossings (in which case the sub-population would segregate again, unless the differences were due to a single gene and the selected population had the recessive phenotype). For example in the case of "Rosa" and "Gordo rojo" populations, the main difference between the subpopulations corresponded to a different skin color (transparent or yellow) and thus an external ripe color (pink or red).

Some of the varieties with a generic local name were ascribed to a known variety considering the site of collection and morphology. A set of 137 populations that did not segregate during 2009 or that included selected sub-populations of segregant populations, the four populations purchased from local nurseries and the four reference hybrids were also characterized during the year 2010. Considering the amount of traits used in the characterization, a principal component analysis was performed to analyse the structure of variation. The first two components, explaining $38 \%$ of the total observed variation, were selected following the criterion described by Krzanowski (2000). The first component (PC1) accounted for $26 \%$ of this variation, being positively correlated with pericarp thickness/fruit width ratio and fruit shape and negatively correlated with fruit width among other variables (Figure 1). The second component (PC2) explained $12 \%$ of the total variation, being positively correlated with pericarp thickness, fruit width/fruit height ratio, style position, intensity of fruit ribbing and negatively correlated with fruit blossom end shape and fruit height amongst other variables.

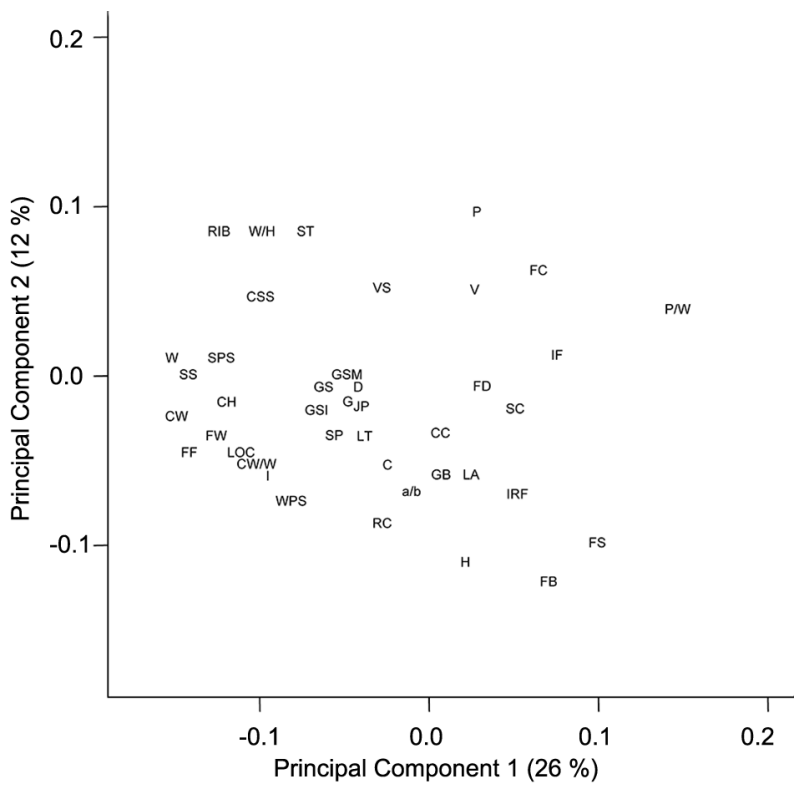

Figure 1 - Loadings obtained for the first two principal components obtained through principal component analysis using all the evaluated descriptors and the means obtained during two campaigns of characterization. (Figure codes: FW: fruit weight, FC: fruit conservation, G: plant growth type, V: plant vigor, RC: radial cracking, CC: concentric cracking, C: external ripe fruit color, a/b: Hunter $\mathrm{a} / \mathrm{b}$ ratio, LOC: number of locules, $\mathrm{W}$ : fruit width, $\mathrm{H}$ : fruit height, W/H: fruit width/fruit height ratio, $\mathrm{CW}$ : core width, $\mathrm{CH}$ : core height, CW/W: core width/fruit width ratio, P: pericarp thickness, P/W: pericarp thickness/fruit width ratio, D: approximate density, CSS: fruit cross-sectional shape, IRF: internal ripe fruit color, SC: skin color of ripe fruit, RIB: intensity of fruit ribbing, S: fruit shape, LT: leaf type, SP: stem pubescence, LA: leaves attitude, FD: foliage density, I: inflorescence type, VS: presence of vegetative shoots in the inflorescence, FF: flower fasciation, ST: style position, IF: external color of immature fruit, GS: presence of green shoulders, GB: intensity of greenback, SS: fruit shoulder shape, GSI: presence of green stripes in immature fruit, GSM: presence of green stripes in mature fruit, JP: presence/absence of jointless pedicel, FB: fruit blossom end shape, WPS: width of pedicel scar and SPS: shape of pistil scar).

High morpho-agronomical variability was detected, both at inter-varietal and intra-varietal levels (Figure 2). This high degree of variation was evident in the "Cuarenteno", "Gordo Rojo", "Rosa" and "Muchamiel" varieties, but was especially important in "De Colgar" and "Valenciano", which showed the widest areas of distribution in the PCA. Nevertheless, most of the populations belonging to each variety tended to show some level of grouping in the PCA for most varieties. An extreme example of grouping could be found in the "Pimiento" variety. The populations of this variety were highly grouped and plotted separately from the other populations. The reason for this separation was the unusual elongated pepper shape, low number of locules, relatively thick 
pericarp, small core and the high degree of hollowness of the variety, characteristics related to its utilization in the preparation of cooked sauces.

The rest of the populations formed a continuous distribution in the PCA, with some degree of overlap between the areas of distribution of different varieties. In fact, more differences could be found in several cases between populations of the same variety than between populations of different varieties. In the case of "GordoRojo" and "Rosa", the populations were mixed in the same area of the PCA, sharing similar characteristics but with a different peel color (yellow vs. transparent) and external color (red vs. pinkish).

In the case of the "De colgar" variety the populations evaluated tended to show high PC1 (most of the populations had small sizes) and PC2 values, but three populations stood apart from the main group. Accession CDP06914 (figure code 4.4) was grouped with "Cuarenteno" tomatoes due to its slightly flattened shape, its bigger fruit size and its higher fruit weight, core width and locule number. Accession CDP01972 (figure code 4.10) had flattened fruit shape, bigger fruit size, higher fruit weight and higher degree of ribbing. With these characteristics this accession plotted relatively close to "Muchamiel" tomatoes. Accession CDP02554 (figure code 4.9) showed a more elongated shape than the rest and was plotted close to populations of the "De Pera" variety.
The two varieties with the highest number of populations evaluated "Muchamiel" and "Valenciano", had a central area of distribution with several populations grouped closely and other populations in proximity. In the case of "Valenciano" the area of distribution was wider. This variety tends to be considered a subtype by farmers since both are heart-shaped. The "Masclet" subgroup is usually characterized by medium sized fruit with a more pointed shape, while "Blanca" typically shows less pointed and bigger sized fruit. Nevertheless, both subgroups could not be distinguished in this PCA nor in a separate PCA considering this variety only (data not shown), as the distribution of both of them was mixed.

The rest of the varieties, were mainly placed within the area delineated by the distribution of the "Muchamiel" and "Valenciano" varieties in PC2 and "De Pera" and "Rosa" in PC1. This was the case for the "Cuarenteno" variety, an obsolete rather than a traditional variety with some resemblance to "Muchamiel" but with a lower intensity of ribbing and a less flattened shape.

A second PCA analysis was performed, reducing the number of variables to nine, to represent those traits easily identifiable by farmers. The first two components explained $71 \%$ of the total variation observed. The first component (PC1) accounted for $51 \%$ of this variation and was positively correlated with all variables except

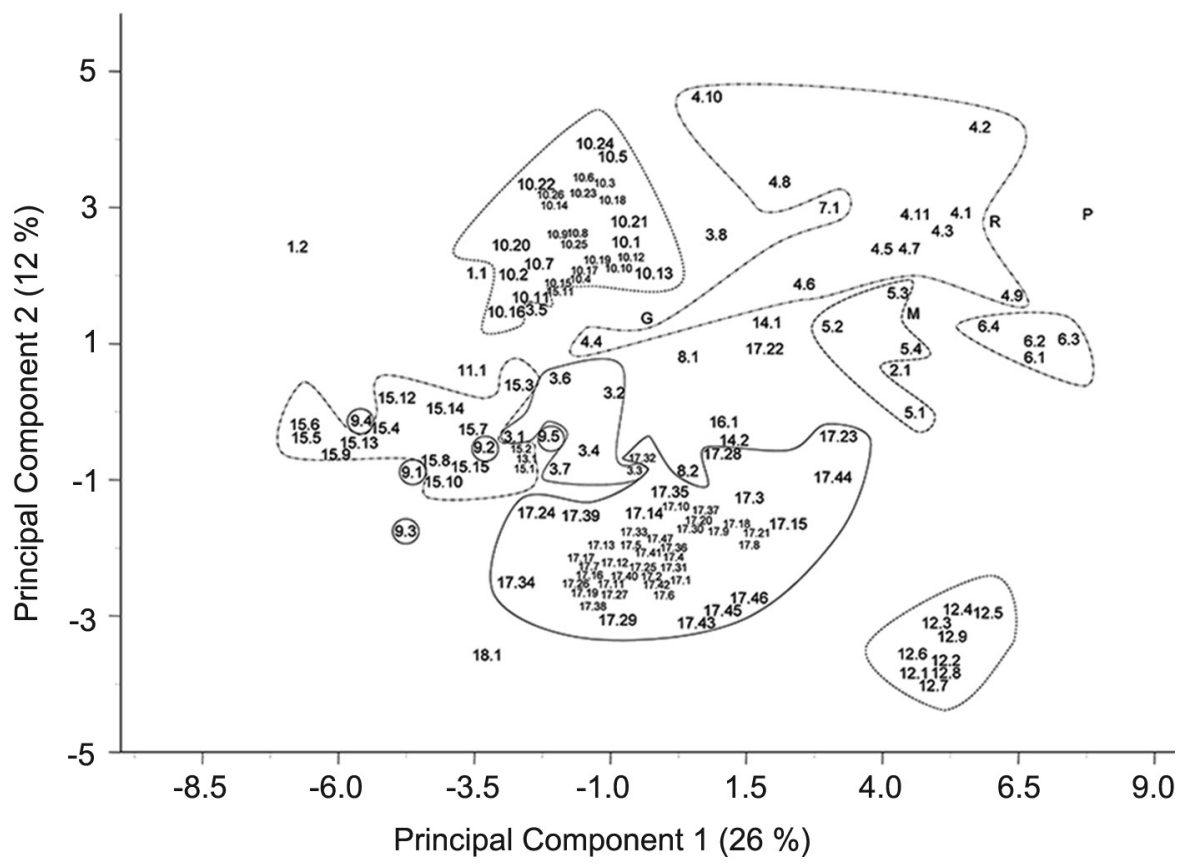

Figure 2 - Plot of the first two principal components obtained through Principal Component Analysis using all the evaluated descriptors and the means obtained during two years of characterization (in parentheses the percentage of variation explained by each component). (Codes $x . x$ indicate variety 1: "Amarillo"; 2: "Centenares"; 3: "Cuarenteno"; 4: "De colgar"; 5: "De la pera"; 6: "De pera"; 7: "Elchero"; 8: "Flor de baladre"; 9: "Gordo rojo"; 10: "Muchamiel"; 11: "Negro"; 12: "Pimiento"; 13: "Raf"; 14: "Redondo rojo"; 15: "Rosa"; 16: "Tres cantos"; 17: "Valenciano"; 18: "Valenciano rosa" and population; P: "Piccota RZ"; G: "Gransol RZ”); M: "Mariscal RZ"; R: "Razymo RZ"). 
ripe fruit color (Hunter $\mathrm{a} / \mathrm{b}$ ) and fruit height (Figure 3). The second component (PC2) explained the other $20 \%$, and was positively correlated with fruit height, ripe fruit

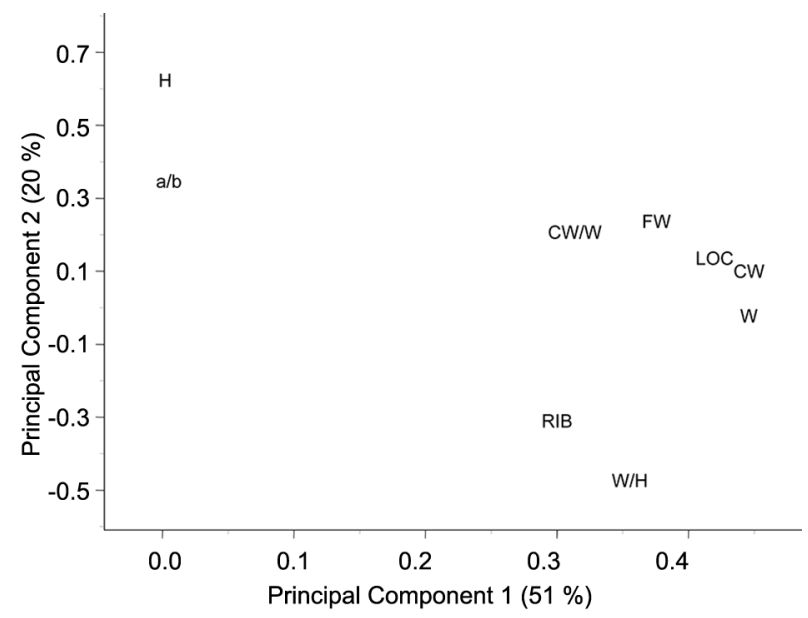

Figure 3 - Loadings obtained for the first two principal components obtained through principal component analysis using a reduced set of descriptors evaluated and the means obtained over two campaigns of characterization. (Figure codes $\mathrm{H}$ : fruit height, a/b: Hunter a/b ratio, RIB: ribbing, W/H Fruit width to height ratio, W, fruit width, FW fruit weight, CW: fruit core width, LOC: number of locules, CW/W: core width to fruit width ratio). color, and to a lesser extent, with fruit weight and core width/fruit width ratio. The PC2 was negatively correlated with fruit width/fruit height ratio and intensity of ribbing.

In this second PCA the results were similar to those obtained with all the variables. In general, populations of the same variety tended to be plotted close together, though some overlap in the areas of distribution of different varieties could be observed and intravarietal variation seemed to be similar or even higher than inter-varietal variation (Figure 4). Again the areas of distribution of "Gordo-Rojo" and "Rosa" completely overlapped.

The area of distribution of "Cuarenteno", which in the complete PCA was placed between "Valenciano" and "Muchamiel", this time appeared overlapped with "Muchamiel". In the collection, the lowest levels of variation $(\mathrm{CCV})$ were obtained for the following vegetative traits: foliage density, leaf type, leaf position plant growth type, plant vigor and stem pubescence, as well as for relatively uniform fruit traits: external and internal ripe fruit color, jointless pedicel and pericarp thickness (Table 2).

In general, the variation found within populations (IACV) was similar or lower than the one observed within a variety (IVCV). IACV was lower than 0.2 in 28 traits, while IVCV was lower than 0.2 in 18 traits. Vegetative traits showed low values of variation at the three levels

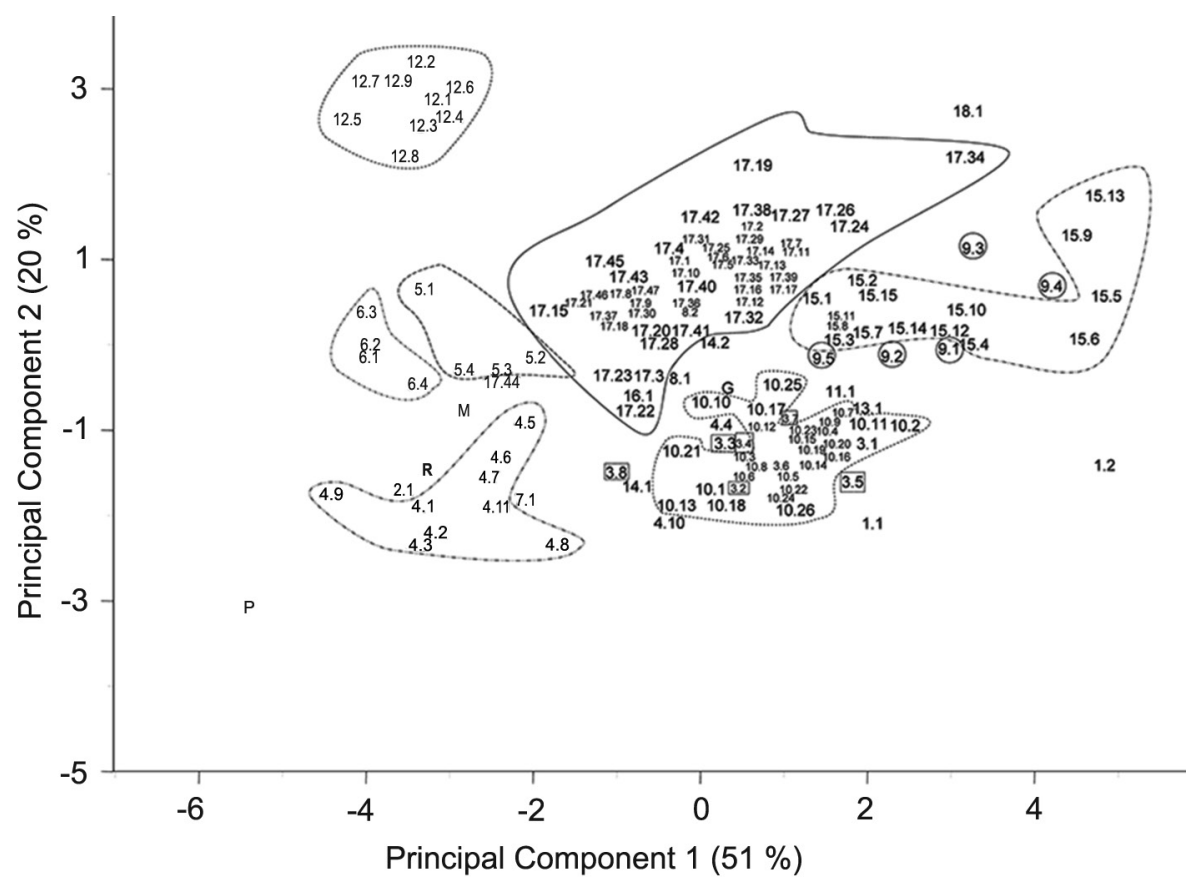

Figure 4 - Plot of the first two principal components obtained through the principal component analysis performed using a reduced set of evaluated descriptors and the means obtained during two campaigns of characterization (in parentheses the percentage of variation explained by each component). (Codes x.x indicate variety 1: "Amarillo"; 2: "Centenares"; 3: "Cuarenteno"; 4: "De colgar"; 5: "De la pera"; 6: "De pera"; 7: "Elchero"; 8: "Flor de baladre"; 9: "Gordo rojo"; 10: "Muchamiel”; 11: "Negro"; 12: "Pimiento"; 13: "Raf”; 14: "Redondo rojo"; 15: "Rosa"; 16: "Tres cantos"; 17: “Valenciano"; 18: "Valenciano rosa” and population; P: "Piccota RZ”; G: "Gransol RZ”); M: "Mariscal RZ”; R: "Razymo RZ”). 
(CCV, IACV and IVCV). Other traits with low levels of variation included external color of ripe fruit (visual classification), internal fruit color (visual classification), pericarp thickness, skin color of ripe fruit and core width to fruit width ratio (Table 2).

In the case of "Valenciano", used as a model for intra-varietal variation, the traits showing the lowest levels of variation (IACV and IVCV) again including vegetative traits and fruit color parameters estimated visually
(Table 3). On the other hand, the traits with higher levels of variation included the presence of green stripe, fruit cracking and the presence of vegetative shoots in the inflorescence, both within and between populations. Although fruit conservation was completely stable within populations, it was very variable between populations. Fruit width and height had low variation compared to fruit weight, number of locules and to fruit width to height ratio. Pericarp thickness was also quite stable.

Table 3 - Variability found in the variety "Valenciano" for the traits characterized, including intra-accession coefficient of variation (IACV) and intravarietal coefficient of variation (IVCV). Values determined in terms of mean coefficients (2009 and 2010).

\begin{tabular}{|c|c|c|c|c|c|c|}
\hline \multirow{2}{*}{ Trait (I:IPGRI, A: Internal) } & \multicolumn{3}{|c|}{$\mid \mathrm{ACV}^{1}$} & \multicolumn{3}{|c|}{$\mathrm{IVCV}^{2}$} \\
\hline & Mean & Min & Max & Mean & Min & Max \\
\hline A-Approximate density $\left(\mathrm{g} \mathrm{mm}^{-3}\right)$ & $0.22 \pm 0.08$ & 0.14 & 0.31 & $0.13 \pm 0.03$ & 0.09 & 0.16 \\
\hline I-Concentric cracking & $0.76 \pm 0.76$ & 0.00 & 1.53 & $0.83 \pm 0.20$ & 0.63 & 1.03 \\
\hline A-Core height (mm) & $0.29 \pm 0.04$ & 0.25 & 0.34 & $0.23 \pm 0.07$ & 0.16 & 0.30 \\
\hline A-Core width (mm) & $0.30 \pm 0.03$ & 0.27 & 0.33 & $0.25 \pm 0.05$ & 0.20 & 0.30 \\
\hline A-Core width/fruit width ratio & $0.18 \pm 0.07$ & 0.12 & 0.25 & $0.13 \pm 0.04$ & 0.09 & 0.18 \\
\hline I-External color of immature fruit & $0.15 \pm 0.01$ & 0.14 & 0.16 & $0.35 \pm 0.13$ & 0.22 & 0.48 \\
\hline I-External ripe fruit color & $0.03 \pm 0.00$ & 0.03 & 0.03 & $0.08 \pm 0.04$ & 0.05 & 0.12 \\
\hline A-Flower fasciation & $0.21 \pm 0.08$ & 0.12 & 0.29 & $0.39 \pm 0.21$ & 0.19 & 0.60 \\
\hline I- Foliage density & $0.00 \pm 0.00$ & 0.00 & 0.01 & $0.07 \pm 0.01$ & 0.06 & 0.08 \\
\hline I-Fruit blossom end shape & $0.09 \pm 0.05$ & 0.03 & 0.14 & $0.19 \pm 0.03$ & 0.16 & 0.22 \\
\hline A-External ripe fruit color (Hunter $\mathrm{a} / \mathrm{b}$ ratio) & $0.22 \pm 0.01$ & 0.20 & 0.23 & $0.20 \pm 0.10$ & 0.10 & 0.30 \\
\hline A-Fruit conservation & $0.00 \pm 0.00$ & 0.00 & 0.00 & $3.87 \pm 0.00$ & 3.87 & 3.87 \\
\hline I-Fruit cross-sectional shape & $0.06 \pm 0.06$ & 0.00 & 0.13 & $0.25 \pm 0.10$ & 0.14 & 0.35 \\
\hline I-Fruit height (mm) & $0.11 \pm 0.01$ & 0.10 & 0.12 & $0.15 \pm 0.07$ & 0.09 & 0.22 \\
\hline I-Fruit shape & $0.09 \pm 0.05$ & 0.04 & 0.14 & $0.42 \pm 0.19$ & 0.23 & 0.61 \\
\hline I-Fruit shoulder shape & $0.10 \pm 0.07$ & 0.04 & 0.17 & $0.20 \pm 0.02$ & 0.18 & 0.22 \\
\hline I-Fruit weight (g) & $0.27 \pm 0.03$ & 0.25 & 0.30 & $0.28 \pm 0.08$ & 0.19 & 0.36 \\
\hline - Fruit width (mm) & $0.11 \pm 0.00$ & 0.11 & 0.12 & $0.14 \pm 0.06$ & 0.08 & 0.19 \\
\hline A-Fruit width/fruit height ratio & $0.23 \pm 0.10$ & 0.13 & 0.33 & $0.24 \pm 0.04$ & 0.20 & 0.28 \\
\hline Hnflorescence type & $0.15 \pm 0.04$ & 0.11 & 0.18 & $0.25 \pm 0.05$ & 0.20 & 0.30 \\
\hline Intensity of fruit ribbing & $0.22 \pm 0.11$ & 0.11 & 0.32 & $0.42 \pm 0.04$ & 0.38 & 0.45 \\
\hline I-Internal ripe fruit color & $0.01 \pm 0.01$ & 0.00 & 0.02 & $0.04 \pm 0.04$ & 0.00 & 0.09 \\
\hline Heaf type & $0.00 \pm 0.00$ & 0.00 & 0.01 & $0.01 \pm 0.01$ & 0.00 & 0.02 \\
\hline H-Leaves attitude & $0.04 \pm 0.02$ & 0.03 & 0.06 & $0.14 \pm 0.01$ & 0.13 & 0.16 \\
\hline I-Number of locules & $0.25 \pm 0.02$ & 0.23 & 0.28 & $0.27 \pm 0.08$ & 0.20 & 0.35 \\
\hline I-Pericarp thickness (mm) & $0.20 \pm 0.03$ & 0.17 & 0.23 & $0.08 \pm 0.01$ & 0.07 & 0.09 \\
\hline A-Pericarp thickness/fruit width ratio & $0.17 \pm 0.01$ & 0.16 & 0.19 & $0.22 \pm 0.02$ & 0.20 & 0.24 \\
\hline I-Plant growth type & $0.04 \pm 0.01$ & 0.03 & 0.05 & $0.09 \pm 0.02$ & 0.07 & 0.11 \\
\hline A-Plant vigor & $0.01 \pm 0.00$ & 0.01 & 0.01 & $0.07 \pm 0.02$ & 0.05 & 0.09 \\
\hline A-Presence of green stripes in immature fruit & $0.89 \pm 0.18$ & 0.71 & 1.07 & $0.98 \pm 0.26$ & 0.71 & 1.24 \\
\hline I-Presence of green shoulders in immature fruit & $0.06 \pm 0.03$ & 0.03 & 0.09 & $0.28 \pm 0.01$ & 0.27 & 0.30 \\
\hline A-Presence of green shoulders in mature fruit & $0.19 \pm 0.09$ & 0.10 & 0.29 & $0.28 \pm 0.02$ & 0.26 & 0.30 \\
\hline A-Presence of green stripes in mature fruit & $0.50 \pm 0.07$ & 0.43 & 0.58 & $1.68 \pm 1.04$ & 0.64 & 2.73 \\
\hline A-Presence of vegetative shoots in the inflorescence & $0.67 \pm 0.50$ & 0.18 & 1.17 & $2.20 \pm 0.61$ & 1.59 & 2.80 \\
\hline I-Presence/absence of jointless pedicel & $0.00 \pm 0.00$ & 0.00 & 0.00 & $0.00 \pm 0.00$ & 0.00 & 0.00 \\
\hline I-Radial cracking & $0.40 \pm 0.40$ & 0.00 & 0.80 & $0.35 \pm 0.03$ & 0.32 & 0.38 \\
\hline I-Shape of pistil scar & $0.22 \pm 0.12$ & 0.11 & 0.34 & $0.25 \pm 0.10$ & 0.15 & 0.35 \\
\hline I-Skin color of ripe fruit & $0.01 \pm 0.01$ & 0.00 & 0.02 & $0.13 \pm 0.13$ & 0.00 & 0.26 \\
\hline I-Stem pubescence & $0.03 \pm 0.01$ & 0.02 & 0.04 & $0.12 \pm 0.05$ & 0.07 & 0.17 \\
\hline I-Style position & $0.07 \pm 0.01$ & 0.06 & 0.09 & $0.34 \pm 0.01$ & 0.34 & 0.35 \\
\hline I-Width of pedicel scar & $0.13 \pm 0.06$ & 0.07 & 0.19 & $0.19 \pm 0.06$ & 0.13 & 0.25 \\
\hline
\end{tabular}

IIntra-accession coefficient of variation (IACV): coefficient of variation of the values from the plants of a single accession; 2Intra-varietal coefficient of variation (IVCV): coefficient of variation of the means of the $n$ populations of a variety. 
Considering all the varieties analysed, the variability found within the accessions (IACV) was lower than the variability found among the means of the accessions (IVCV) belonging to the variety (table 4). The IACV obtained for traditional varieties was in general higher than that obtained in the hybrid controls. Nevertheless similar values were obtained in the "De la pera", "Flor de baladre" and "Valenciano rosa" varieties. The highest values of IVCV were obtained in the "Rosa", "Valenciano", "Gordo rojo", "De colgar" and "Cuarenteno" varieties.

\section{Discussion}

As a secondary center of diversity, Spain counts with a rich diversity reflected in the wide range of variation in the collection of populations of traditional varieties or landraces evaluated in this work. Despite the level of diversity, a restricted amount of information is known about the structure of traditional varieties. The records available in passport data of the main Spanish collections, as the Institute for the Conservation and Improvement of Valentian Agrodiversity, COMAV, show that in a considerable number of cases, the traditional materials collected lack a specific varietal name, or that materials collected at distinct places share the same name (which usually refers to external features such as color or the culinary use). This inconsistency in varietal designation

Table 4 - Variability found in the varieties characterized, including intra-accession coefficient of variation (IACV) and intra-varietal coefficient of variation (IVCV). Values expressed as the mean (for all the traits) \pm standard deviation for both years and maximum value obtained for a single trait.

\begin{tabular}{|c|c|c|c|c|}
\hline \multirow{2}{*}{ Variety } & \multicolumn{4}{|c|}{$\mathrm{IACV}^{1}$} \\
\hline & Mean & $\operatorname{Max}$ & Mean & Max \\
\hline "Amarillo" & $0.22 \pm 0.04$ & 2.27 & $0.18 \pm 0.02$ & 1.41 \\
\hline "Centenares" & $0.16 \pm 0.03$ & 1.57 & - & - \\
\hline "Cuarenteno" & $0.16 \pm 0.00$ & 1.31 & $0.35 \pm 0.02$ & 2.83 \\
\hline "De colgar" & $0.17 \pm 0.00$ & 1.01 & $0.36 \pm 0.00$ & 2.02 \\
\hline "De la pera" & $0.11 \pm 0.04$ & 0.98 & $0.26 \pm 0.07$ & 2.00 \\
\hline "De pera" & $0.15 \pm 0.04$ & 2.45 & $0.27 \pm 0.03$ & 2.00 \\
\hline "Elchero" & $0.18 \pm 0.02$ & 4.47 & - & - \\
\hline "Flor de baladre" & $0.13 \pm 0.03$ & 1.08 & $0.17 \pm 0.03$ & 1.41 \\
\hline "Gordo rojo" & $0.16 \pm 0.00$ & 0.91 & $0.37 \pm 0.06$ & 2.24 \\
\hline "Muchamiel" & $0.22 \pm 0.03$ & 1.50 & $0.32 \pm 0.04$ & 2.88 \\
\hline “Negro" & $0.28 \pm 0.04$ & 4.58 & - & - \\
\hline "Pimiento" & $0.21 \pm 0.06$ & 1.61 & $0.32 \pm 0.03$ & 3.00 \\
\hline "Redondo rojo" & $0.18 \pm 0.00$ & 1.65 & $0.26 \pm 0.09$ & 1.41 \\
\hline “Rosa" & $0.17 \pm 0.02$ & 1.58 & $0.42 \pm 0.16$ & 3.87 \\
\hline "Tres cantos" & $0.17 \pm 0.05$ & 3.08 & $0.00 \pm 0.00$ & 0.00 \\
\hline "Valenciano" & $0.19 \pm 0.00$ & 1.53 & $0.41 \pm 0.08$ & 3.87 \\
\hline "Valenciano rosa" & $0.11 \pm 0.08$ & 2.05 & - & - \\
\hline "Raf" & $0.26 \pm 0.10$ & 2.80 & - & - \\
\hline Hybrid controls & $0.11 \pm 0.02$ & 1.32 & $0.32 \pm 0.02$ & 2.00 \\
\hline
\end{tabular}

applies also to other crops and areas, such as cassava in South America (Salick et al., 1997). But, in these cases, it is still possible to reclassify these materials in order to provide better organization of the accessions maintained in genebanks. In fact, the characterization performed in this work revealed that, considering the fruit morphology and site of collection, some of the materials with a generic name, e.g. "tomato" or "salad tomato", could be ascribed to a certain variety.

Another problem that adds difficulties in the analysis of the structure of traditional varieties is the existence of segregating populations. In fact, in this study, segregation has been observed in several populations. Although in some cases the segregation may have been caused during conservation procedures (seed mixing prior to collection cannot be ruled out), in most cases, segregants were identified in original seed lots. Obviously, in these cases, the cause of the segregation observed should have emerged before the collection. Segregating or seed mixture populations have also been found in traditional tomato varieties in other areas, for example, in the "Corbarino" variety from Italy (Andreakis et al., 2004), though in that case, it remained unclear if that situation arose during the conservation process in the genebank or previously.

In our opinion, those cases in which sub-population structure could be identified as having originated as a consequence of seed exchange between farmers and seed mixing. This would explain how it was possible to clearly differentiate groups of plants within a number of the populations. These cases could be easily depurated, recovering seed on a per-plant basis.

Seed exchange and mixing is quite usual among farmers. In some cases, new varieties are obtained from other farmers and on other occasions the seed exchange is related to seed degeneration. In previous works based on prospection, farmers held the idea that seed degenerates. For "fresh materials" to be obtained, seeds of the same variety from neighbour farmers are obtained, and eventually seeds from different origins get mixed (Cebolla-Cornejo et al., 2007). Terzopoulus and Bebeli (2010) observed in the morphological characterization of Greek tomato landraces that the majority of genotypic variation was found within landraces, especially in fruit traits. They also suggested seed exchange between farmers as a key explanation for the high level of variation observed. This idea of seed degeneration and replacement is not restricted to this region, and has also been reported in other European countries and in other crops (Zeven, 1999).

In other cases, such as the case of the mixes of "Rosa" and "Gordo rojo", the subpopulations could have originated either from seed mixing of varieties or as spontaneous crosses between these two varieties being grown simultaneously. These varieties have populations of large and medium-sized fruit and generally the difference between them lies in the pink or red external color (due to the transparent or yellow skin color respective- 
ly). The mutation yellow $(y)$ determines the colorless skin color in tomato and is controlled by a gene coding a transcription factor that results in the lack of the ripeningdependent accumulation of the yellow-colored flavonoid naringenin chalcone in the fruit peel, while carotenoid levels are not affected (Ballester et al., 2010). Therefore, considering that the main difference between the varieties relies on a single gene, when a spontaneous cross between them occurs it would be easy to distinguish two sub-populations in the progeny. These populations can be depurated, as a simple segregation is expected and using single plant selections, the populations can be fixed in two or three generations.

In other cases, where a continuous gradient of variation is identified within the population, it would be due to spontaneous crossings between different varieties that had been grown at the same time. These cases might not be depurated, as a continuous segregation is expected in the following generations.

Considering non-segregating populations, the high variability observed in some varieties such as the "De colgar" variety (also known as "De penjar") was expected. In this particular case, the variety usually includes fruit with different shapes, sizes (though usually small) and colors, but with the common traits of delayed ripening and long shelf life. This delayed ripening is due to the alcobaça (alc) mutation, which corresponds to an allele of the non-ripening, nor, gene (Casals et al., 2012). It seems that this allele would have been accidentally introgressed in different genetic backgrounds following spontaneous crossings and that the farmers would have applied a strong selection for the delayed ripening trait. As a side effect, selection would probably have resulted in small fruit size as this feature is correlated with of long shelf life. Consequently, a great level of variation would have been expected, and in fact was found, in morpho-agronomical traits among the populations of this variety. Bota et al. (2014) confirmed this structure in "Ramellet" tomatoes, a Balearic variant of "De colgar" tomatoes.

In other cases, such as in the case of "Rosa" or "Gordo rojo", apart from the possible existence of spontaneous crossings between them, the variability would also be related to their geographical distribution. Unlike other cases such as "Muchamiel" or Valenciano" with a clear and restricted geographical distribution, the former varieties are typical of inland cultivation of tomato and have a wider distribution of cultivation area. In these cases, selections for different fruit sizes and fruit ribbing could have occurred. Nonetheless, the variation found considering all the traits analysed in the accessions of the same variety, (IVCV) was similar in "Valenciano" and "Rosa".

The structure of traditional varieties of tomato characterized seems more complex than previously expected. A high degree of variation is found on an intrapopulation and intra-varietal basis. It seems that spontaneous crossings and seed mixing are relatively frequent.
Despite being a self-pollinating species, spontaneous cross-pollination rates in tomato can reach $2-4 \%$, but in high temperature conditions style exertion is promoted (Dorais et al., 2001; Levy et al., 1978) and this rate may increase. Additionally, there is genotype dependence on the trait (Lesley, 1924) and in the case of the traditional varieties assayed style exertion was detected in several populations. In the case of traditional varieties of tomato, the majority of the farmers that still maintain these materials, tend to grow together a low number of plants of different species and varieties. In fact, a survey carried out in the area proved that most of the smallholdings maintaining traditional varieties had less than 40 plants of tomato (Cebolla-Cornejo et al., 2007). In these cases, the proximity of plants of different varieties and spontaneous cross-pollination would facilitate segregation in their progeny.

After natural cross-pollination events, farmers would apply strong selection on the progeny, especially in the main features that identify a certain variety. The different selection performed by different farmers would lead to a high degree of intra-varietal diversity, higher than intra-accession variability. Consequently, a wide dispersion of populations of the same variety would be expected in a PCA with morpho-agronomic traits, as was observed in this study. In a more detailed analysis using only two Spanish varieties "Pera de Girona" and "Monstserrat", Casals et al. (2011) also concluded that traditional varieties might be differentiated in a very reduced number of fruit morphological traits (four in that case) with strong selection pressure in the key ones (one in that case). Grajera-Facundo et al. (2011) also stressed that the number of discriminatory descriptors in the characterization of traditional varieties would be limited. The restricted number of traits defining these materials seems comparable to other crops. Cleveland et al. (2000), in the analysis of farmer's plant breeding strategies concluded that the number of traits that define a varietal type might be significantly reduced. For example, in the case of maize it would include grain type, grain form and cob and husk color.

In our case, a selection of 9 traits out of 41 still maintained a differentiation of varietal groups. It seems that fruit size, shape, ribbing and color are essential characteristics for the definition of a variety, though a high degree of variation would be found in the continuous measurement of these traits within the same variety. A lower variation would be expected in traits not usually considered by farmers during selection as in vegetative traits, while higher variation would be expected in fruit traits. The results obtained confirm these trends. Although "Valenciano" is defined by the heart-shape of its fruit, a relatively high variation is found in traits related to fruit size (fruit weight, number of locules), shape (fruit width to height ratio) appearance (green stripes) or agronomic performance (cracking or presence of vegetative shoots in inflorescences). 
Additionally, although farmers recognize the "Masclet" and "Blanca" subtypes, it is difficult to differentiate them in a PCA, considering the high level of continuous variation for both groups. In previous studies, the high variability of varieties such as "Valenciano" has been confirmed (Cebolla-Cornejo et al., 2013). In fact, it also affected agronomical traits such as fruit weight, plant yield and chemical composition related to taste. This high diversity is not reflected at the molecular level, at least with AFLP markers (Cebolla-Cornejo et al., 2013). In this case, the lack of relation has been explained by the relatively low genetic diversity of tomato (Villand et al., 1998) and the fact that key morphological traits are controlled by a limited number of genes (Tanksley, 2004).

The high selection pressure on certain traits defining a variety would still generate some variation if different states of these traits were selected with different purposes or areas of cultivation. That would be why heterogeneity even in fruit shapes within the same variety seems to be quite spread. For example, the Greek variety "Santorini" shows different morphologies depending on the use given: rounded for juice and preserves, and flattened fruit for producing sun-dried tomatoes (Terzopoulos and Bebeli, 2010). Similarly, in the case of the Italian traditional variety "A pera Abruzzese" Mazzucato et al. (2010) observed predominantly round fruit, but also flattened and obovoid fruit in a considerable number of cases (20 and $24 \%$ respectively).

In the context of the management of ex situ collections of genetic resources in germplasm banks this structure leads to the following question: To what extent should the collection of a certain traditional variety be prolonged? Populations collected at relatively close sites, with the same local name and certain common characteristics, still differ considerably. Therefore, they cannot be strictly considered as duplicates as their conservation still enables the conservation of different traits. In fact, it would be necessary to carefully prospect each traditional variety in order to acquire a representative sample of the intra-varietal diversity.

Regarding in situ conservation another question arises: is there really a place for on-farm conservation of all this diversity? At least in Spain, quality niche markets, where the consumers are willing to pay a higher price for increased organoleptic quality, have emerged in a process linked with the decrease in this characteristic in modern tomato cultivars (Bruhn et al., 1991). This difference can command up to 4.7 times the price of conventional varieties (Cebolla-Cornejo et al., 2007). This price premium compensates for the lower yield of traditional varieties as compared to modern bred varieties, thus rendering their cultivation and on-farm conservation economically feasible.

Nonetheless, the existence of a continuous gradient of variation in traditional varieties of tomato involves several problems from the point of view of their in situ conservation in on-farm programs. First of all, the consolidation of these quality niche markets, at least for these tomato varieties, depends on clear recognition by the consumer, but it is difficult when so much variation is present in the same variety. Therefore, it would be necessary to depurate the variety, selecting a certain representative population of the average morpho-type. This depuration would also enable for example, in the case of Europe, the registration of these traditional varieties as conservation varieties. In that case, it should be considered that with the detected levels of intra-accession variation even conceding wider ranges of variation for these varieties, it would be very difficult to pass the technical DUS analysis (distinctness, uniformity and stability) if on the basis of off-types, a population standard of $10 \%$ and an acceptance probability of at least $90 \%$ is applied (Commission Directive $2008 / 62 / \mathrm{EC})$.

Initial results of the European Project Farm Seed Opportunities already showed that traditional varieties conformed as population varieties would be able to verify the uniformity and stability criteria for a few traits only (Chable et al., 2009). Therefore, it would be necessary to make intra-population selections in order to increase the level of uniformity. Obviously, as a result, the structure of this depurated traditional variety would not correspond to the initial one and this might raise some questions regarding the effectiveness of the process in conserving diversity.

Even discarding the registration as conservation varieties, the depuration would be necessary as wide diversity in organoleptic quality characteristics is also present (Cortés-Olmos et al., 2011) and not all the population of a certain traditional variety would respond to the high quality standards demanded by quality niche markets. A clear identification by the consumer, and the assurance of high organoleptic quality would enable the establishment of a clear link between external appearance and internal quality, a step necessary for the consolidation of the price premium in niche markets. Additionally, the existence of plants within a population with considerably lower agronomic performance, as recorded in Cebolla-Cornejo et al. (2013) has already raised the question as to how to juggle the variation present in traditional tomato varieties and the economic viability necessary for successful on-farm conservation.

Traditional varieties of tomato were used as the base for the development of modern tomato varieties during the XIX and early XX centuries. In the 40s the focus on the source of variation required for the development of breeding programs moved to wild species related to the tomato. As a result, numerous genes coding resistance to pathogens and specifically virus have been identified and tomato yield increased dramatically (Tanksley and McCouch, 1997). But currently, with consumers beginning to demand higher quality in the tomato market, the focus should revert back again to traditional varieties, with recognized organoleptic quality. 


\section{Acknowledgements}

The funds for the development of this research were provided by the Foundation of Comunidad Valenciana for Agricultural and Food Reaearch (AGROALIMED). Carles Cortes-Olmos expresses his gratitude to Polytechnic University of Valencia for the provision of a PhD grant.

\section{References}

Alonso, A.; Vázquez-Araújo, L.; García-Martínez, S.; Ruiz, J.J.; Carbonell-Barrachina, Á.A. 2009. Volatile compounds of traditional and virus-resistant breeding lines of Muchamiel tomatoes. European Food Research and Technology 230: 315-323.

Andreakis, N.; Giordano, I.; Pentangelo, A.; Fogliano, V.; Graziani, G.; Monti, L.M.; Rao, R. 2004. DNA Fingerprinting and quality traits of corbarino cherry-like tomato landraces. Journal of Agricultural and Food Chemistry 52: 3366-3371.

Ballester, A.; Molthoff, J.; De Vos, R.; Hekkert, B.T.L.; Orzaez, D.; Fernández-Moreno, J.; Tripodi, P.; Grandillo, S.; Martin, C.; Heldens, J.; Ykema, M.; Granell, A.; Bovy, A. 2010. Biochemical and molecular analysis of pink tomatoes: deregulated expression of the gene encoding transcription factor SIMYB12 leads to pink tomato fruit color. Plant Physiology 152: 71-84.

Bota, J.; Conesa, M.À.; Ochogavia, J.M.; Medrano, H.; Francis, D.M.; Cifre, J. 2014. Characterization of a landrace collection for Tomàtiga de Ramellet (Solanum lycopersicum L.) from the Balearic Islands. Genetic Resources and Crop Evolution 61: 1131-1146.

Bruhn, C.M.; Feldman, N.; Garlitz, C.; Harwood, J.; Ivans, E.; Marshall, M.; Riley, A.; Thurber, D.; Williamson, E. 1991. Consumer perceptions of quality: apricots, cantaloupes, peaches, pears, strawberries, and tomatoes. Journal of Food Quality 14: 187-195

Casals, J.; Pascual, L.; Cañizares, J.; Cebolla-Cornejo, J.; Casañas, F.; Nuez, F. 2011. The risks of success in quality vegetable markets: Possible genetic erosion in Marmande tomatoes (Solanum lycopersicum L.) and consumer dissatisfaction. Scientia Horticulturae 130: 78-84.

Casals, J.; Pascual, L.; Cañizares, J.; Cebolla-Cornejo, J.; Casañas, F; Nuez, F. 2012. Genetic basis of long shelf life and variability into Penjar tomato. Genetic Resources and Crop Evolution 59: 219-229.

Cebolla-Cornejo, J.; Soler, S.; Nuez, F. 2007. Genetic erosion of traditional varieties of vegetable crops in Europe: tomato cultivation in Valencia (Spain) as a case study. International Journal of Plant Production 1: 113-128.

Cebolla-Cornejo, J.; Roselló, S.; Nuez, F. 2013. Phenotypic and genetic diversity of Spanish tomato landraces. Scientia Horticulturae 162: 150-164.

Cleveland, D.; Daniela, S.; Smith, S. 2000. A biological framework for understanding farmers' plant breeding. Economic Botany 54: 377-394.

Chable, V.; Goldringer, I.; Dawson, J.; Bocci, R.; Bueren, E.L. van; Serpolay, E.; González, J.M.; Valero, T.; Levilla, T. 2009. Farm seed opportunities: a project to promote landrace use and renew biodiversity. p. 266-274. In: Veteläinen, M.; Negri, V.; Maxted, N., eds. European landraces: on-farm conservation, management and use. ECP/GR, Maccarese, Italy.
Cortés-Olmos, C.; Leiva-Brondo, M.; Adalid, A.M.; CebollaCornejo, J.; Nuez, F. 2011. Identification of organoleptic and functional quality profiles in Spanish traditional cultivars of tomato. Acta Horticulturae 918: 501-508.

Dorais, M.; Papadopoulos, A.; Gosselin, A. 2001. Greenhouse tomato fruit quality. Horticultural Reviews 26: 239-319.

García-Martinez, S.; Andreani, L.; García-Gusano, M.; Geuna, F.; Ruiz, J.J. 2006. Evaluation of amplified fragment length polymorphism and simple sequence repeats for tomato germplasm fingerprinting: utility for grouping closely related traditional cultivars. Genome 49: 648-656.

García-Martínez, S.; Corrado, G.; Ruiz, J.J.; Rao, R. 2013. Diversity and structure of a sample of traditional Italian and Spanish tomato accessions. Genetic Resources and. Crop Evolution 60: 789-798.

Gragera-Facundo, J.; Gutiérrez-Perera, J.M.; Gil-Torralvo, C.G.; Ávila-Lozano, J.M.; Cano-Suárez, J.M.; Esteban-Perdigón, A. 2011 Discriminatory morphologic and agronomic characters that identify Spanish tomato landraces. Acta Horticulturae 918: 583-594.

Junta Consultiva Agronómica. 1914. Statistical Advance of the Spanish Richness Represented in the Annual New Production of Industrial Crops and Vegetables = Avance Estadístico de la Riqueza que en España Representa la Producción Media Anual de las Plantas Hortícolas y Plantas Industriales. Ministerio de Fomento, Madrid, Spain. (in Spanish).

Krzanowski, W.J. 2000. Principles of Multivariate Analysis: A User`s Perspective. Oxford University Press, Oxford, UK.

Lesley, J.W. 1924. Cross pollination of tomatoes: varietal differences in amount of natural cross-pollination important factor in selection. Journal of Heredity 15: 233-235.

Levy, A.; Rabinowitch, H.D.; Kedar, N. 1978. Morphological and physiological characters affecting flower drop and fruit set of tomatoes at high temperatures. Euphytica 27: 211-218.

Mazzucato, A.; Ficcadenti, N.; Caioni, M.; Mosconi, P.; Piccinini, E.; Reddy Sanampudi, V.R.; Sestili, S.; Ferrari, V. 2010. Genetic diversity and distinctiveness in tomato (Solanum lycopersicum L.) landraces: the Italian case study of "A pera Abruzzese". Scientia Horticulturae 125: 55-62.

Salick, J.; Cellinese, N.; Knapp, S. 1997. Indigenous diversity of Cassava: generation, maintenance, use and loss among the Amuesha, Peruvian upper Amazon. Economic Botany 51: 6-19.

Tanksley, S.D.; McCouch, S.R. 1997. Seed banks and molecular maps: unlocking genetic potential from the wild. Science 277: 1063-1066.

Tanksley, S.D. 2004. The genetic, developmental, and molecular bases of fruit size and shape variation in tomato. Plant Cell Online 16: S181-S189.

Terzopoulos, P.J.; Bebeli, P.J. 2010. Phenotypic diversity in Greek tomato (Solanum lycopersicum L.) landraces. Scientia Horticulturae 126: 138-144.

Villand, J.; Skroch, P.W.; Lai, T.; Hanson, P.; Kuo, C.G.; Nienhuis, J. 1998. Genetic variation among tomato accessions from primary and secondary centers of diversity. Crop Science 38: 1339-1347.

Zeven, A.C. 1999. The traditional inexplicable replacement of seed and seed ware of landraces and cultivars: a review. Euphytica 110: 181-191. 